\title{
Citation
}

Dabic, M. and Kiessling, T. (2019), "The performance implications of knowledge management and strategic alignment of MNC subsidiaries", Journal of Knowledge Management, Vol. 23 No. 8, pp. 1477 1501. https://doi.org/10.1108/JKM-03-2019-0129

\section{The Performance Implications of Knowledge Management and Strategic}

\section{Alignment of MNC Subsidiaries \\ Introduction}

Global knowledge management has come to the forefront of strategy research due to it being an important source of competitive advantage and sustained superior performance (Foss and Pedersen, 2004; Blomkvist, 2012; Zeng et al., 2018). Researchers are now exploring knowledge management between subsidiaries and headquarters of multinational corporations (MNCs) (Claver-Cortes et al., 2018) yet researchers are still attempting to link knowledge management to a global firms' performance, or how a knowledge-based advantage is sustained (Lee, 2018; Teece, 1998; McEvily and Chakravathry, 2002). Only currently has the research focused on knowledge management amongst MNCs and their subsidiaries (Meyer and Peng, 2016). This limited research is surprising as much theoretical literature either utilizes knowledge as a theoretical platform or suggests that knowledge is a source of competitive advantage (Mudambi, et al., 2014). Our research furthers the knowledge management literature by focusing on whether firms 
with good knowledge management systems will perform better in a transitional economy, in specific that of Croatia which jointed the European Union in 2013.

As multinational corporations (MNC) foreign subsidiaries reside in increasingly diverse environmental contexts, MNCs are attempting to establish complex organizational and strategic arrangements to facilitate global cohesion (Wei and Nguyen, 2017). MNC success depends on how effective subsidiary operations are aligned with local environmental conditions given the context of global competition occurring at the business level in specific markets (Aragon-Sanchez and Sanchez-Martin, 2005). Market conditions therefore affect the knowledge management processes for an MNC (Hong and Snell, 2015). MNC's are now relying on their subsidiaries for knowledge, giving them autonomy for their own operational responsibilities, and developing systems to transfer market knowledge globally (Cadogan, et al., 2009).

Past research suggests that MNCs capable of integrating and utilizing knowledge will develop a sustainable competitive advantage (Crespo et al., 2014; Ferreira et al., 2015; Kirca and Hult, 2009). However, the global strategy literature has focused primarily on the issue of knowledge management, rather than understanding the specific environmental contexts in local markets or the influence of strategic orientation on knowledge management processes. Specifically, there has been little attention so far to the environment-strategyknowledge management-performance (ESKMP) linkage at the MNC subsidiary level (Vanaik and Midgley, 2019; Najafi-Tavani, Robson, Zaefarian, Andersson and Yu, 2018).

Transitional economies have become increasingly important to MNC operations (Li et al., 2016; Lee, 2019; Wahdwa, McCorick and Musteen, 2017). Transitional economies are characterized by highly uncertain and dynamic market conditions. As such, 
the transitional economy context offers a unique opportunity to extend our understanding of the ESKMP relationship. The transition from a socialist to a market economy occurring in Eastern European firms suggest that they will have to develop competencies quickly, build up knowledge bases, and implement innovations (Dabić et al., 2012; Pereira et al., 2018). Currently these local firms are not as competitive to global firms due to high production costs, obsolete machinery, poor infrastructure, poor product quality, insufficient service and older technology (Petrakos, 2013). Prior research on knowledge management has been primarily limited to domestic firms operating mostly in concentrated and stable markets. More importantly, there is little research examining the ESKMP relationship in different institutional settings.

Strategic configurations available in the literature imply that generic strategies are equally viable across environmental contexts. These configurations are also ambiguous in specifying the strategy-environment fit in international market contexts and lack the integration of knowledge management capabilities, which have been purported to enhance a firm's competitive positioning (Frambach et al., 2016). Along with other recent research (Lin, Tsai and Wu, 2014; Ingram et al., 2016), this paper uses the Miles and Snow (1978) typology of strategic orientations as a way for formulating hypotheses about the importance of knowledge management capabilities for MNC subsidiaries. Multinational corporations (MNCs) increasingly understand the important influence between the type of strategic configuration (i.e., Prospector, Analyzer, Defender, Reactor) with their host country environment (Luo and Park, 2001).

Central and Eastern European (CEE) transition economies are major business opportunities, though complex, as socioeconomic problems (e.g., high debt, high 
bureaucracy) hinder MNC's subsidiaries performance (Tihanyi and Roath, 2002). Even with these issues, the CEE has attracted considerable foreign direct investment capturing 23\% of FDI projects in Europe and 52\% of jobs in 2016 (Ernst and Young, 2017). The transitional economies like Croatia are a unique opportunity for researchers to explore business phenomena as suggested by expanded research in the CEE economies (Meyer and Peng, 2005; Meyer and Peng, 2016; Zahra et al., 2000; Meyer, 2016; Peng and Luo, 2000, Luo and Peng, 1999; Peng, 2000; Peterson, 2016). One of the key driving forces is the privatization of state-owned enterprises (SOEs) in the CEE (Frydman, et al., 1998), and are currently manufacturing hubs for European countries (Nelson, 2017). Privatization resulting in employees with a lack of entrepreneurial and managerial skills of the employees (Meyer, 1998) and being a new manufacturing hub has researchers examining the technology and management skills transfers to these CEE organizations (Uhlenbruck and Castro, 2000; Stor et al., 2016 ).

Our research endeavors to explore two research questions:

R1: To add to the knowledge management literature in general; do firms in transitional economies that actually pursue knowledge management have better performance.

R2: Past research suggests that knowledge is a source of competitive advantage, and transitional economies are characterized by uncertain and dynamic market conditions, as such; will MNCs select a Prospector strategy to proactively seek and utilize new market knowledge and opportunities.

Our paper is organized as to the following: First we explore the theoretical foundation of the knowledge-based theory of the organization, second, we analyze the Croatian marketplace and why it is an appropriate setting for our research, third, we 
explore the Miles and Snow framework and give preference for our hypothesis as to why the Prospector strategy will be favored in a transitional economy, fourth, we apply the knowledge management literature and support why knowledge management will be the most used by Prospectors in this marketplace, fifth, we argue how knowledge management by all firms will be a requirement for successful firm performance and then hypothesize why Prospectors will have greater performance, sixth, our methodology section, finally we make conclusions and limitations of our study.

\section{Knowledge-Based Theory of Organizations}

Knowledge management has continued to generate an enormous amount of interest from the early 1990s, with formulative researchers contending that the knowledge-based view represents a fundamentally new theory of the firm (e.g., Nonaka and Takeuchi, 1995). Much of this early research began by distinguishing between information and knowledge and has subsequently delved into the meaning of knowledge, determining how knowledge is generated and disseminated, setting out the foundations of a knowledgebased theory of the firm, and prescribing the adoption of a knowledge perspective (Nonaka, 1994; Kogut and Zander, 1992, 1993; Spender, 1996; Grant, 1996; Teece, 1998, 2000; Nonaka and Teece, 2001; Schultz and Jobe, 2001; Thomas et al, 2001).

The success of a global corporation in foreign markets as well as the accumulation of knowledge from these markets is challenged by the influences of the environments that the foreign subsidiaries operate, thereby suggesting a need for adaption to the local environment for global marketing effectiveness (Kirca et al., 2009 b). Foreign subsidiaries do not necessarily follow corporate strategy in a global corporation in total, and often 
tailor parts of the marketing strategy to the local environment due to effective knowledge management and rely on informal contacts of customers and sales people as a basis for information gathering (Meyer and Su, 2015). These same changes may be utilized in other subsidiaries and could assist in the home office's global strategy.

The marketing strategy of foreign subsidiaries and a corporation's market orientation illustrate that foreign subsidiaries who are able to successfully analyse their local market and provide additional knowledge and add-value will be more successful (Pehrsson, 2009). The local market conditions and environment vary per country due to distribution, market segmentation, local networks and competitor moves and must therefore tailor a portion of the global strategy to their local strategy (Najafi-Tavani et al. 2015).

The success of a global strategy rests within its subsidiaries' locally developed capabilities and less with the corporate headquarters (Ensign et al., 2000) hence researchers are focusing on examining how foreign subsidiary knowledge can be incorporated both in the headquarters and throughout the entire network of subsidiaries (Andersson, Forsgren and Holm, 2002). If a subsidiary does not have knowledge producing capabilities, support for the subsidiary from the global corporation headquarters and allocation of resources in support of the subsidiary will be hindered (Kirca et al., 2009a).

Research suggests that foreign subsidiaries are playing greater roles in global corporation success, and those engaging in product diversification activities or expanding their local presence in related businesses perform better (Chiao et al., 2008). However, there appears to be a dearth in understanding strategy implementation of foreign subsidiaries and how the strategy is a value adding activity (Pehrsson, 2008).

\section{Why Croatia is an Appropriate Setting for the Research}


Croatia transitioning from a socialist economy to a free-market focused is constrained by historical barriers and institutional pressures. Recent research suggests that a weak formal, and strong informal, institutional environment such as is present in Croatia will negatively affect high growth firms (HGFs) (Krasniqi and Desai, 2016), which is of interest as these type of firms have the largest contributions in job creation and economic growth (Coad et al., 2014). Initially, the focus on Croatia's transition was on structural reform and macroeconomic issues, in specific, opening their marketplace to foreign firms. Success has been seen with low inflation and many government-owned institutions have been privatized and are now forced to compete. This has allowed foreign firms to enter the marketplace and have compelled local firms to change rapidly. New knowledge processes and production efficiencies are required to be successful in the transitioning economy. Croatia's transition has shown some success as it has grown from 61rst (in 2006) to 30th in the Global Competitiveness report in 2019 (INSEAD, 2019).

Pent up domestic demand for new goods is a main driver of growth along with increased public spending. The transition into a market oriented economy has brought opportunities but also challenges to the consumer (Cui et al., 2006). Not only has the economy evolved but so also has the buying habits and the transparency in the marketplace, though there is still much change to occur. Croatia has two major strengths: a high quality educated workforce, and its physical location as it is located between the developed markets of Western Europe and the fast growing Southeast (Dabic and Bach, 2008). Although attempting to transition, there are still barriers to free competition, governmental still intervenes in the marketplace, and information is still not always freely available. 
Due to their previous socialist institutions, Croatia is still in the "catch up" mode. For example, in the past, manufacturer's goals were to provide jobs and not be efficient. Currently, there is much innovation in the manufacturing industry to achieve efficiency and provide superior offerings to the consumer. This requires significant knowledge transfer, market knowledge gathering, and knowledge management systems within firms that wish to be competitive in the new dynamic fast-changing marketplace. Research focusing on Central and East European countries (CEECs) exhibits the importance of our research focusing on Croatia. All CEECs are restructuring, are focusing on efficiency of labor, and that Croatia has had the most extensive strategic changes of all CEECs (Stojcic, Hashi and Telhaj, 2011).

Research has illustrated that a country's institutional and economic environments have an impact on a firm's ability to operate as country-specific environments affect both the intensity and type of competition which influence firm strategy. Competitive intensity and dynamism will affect the strategy configuration of a firm. MNC subsidiaries in Croatia still are strategically challenged by a high degree of uncertainty as the government continues to try to influence market imperfections, and there continues to be rapid changes in competition and customer demands (Tihanyi and Roath, 2002). These institutional and marketplace challenges illustrate the need for firms to have strong knowledge management practices to not only seek new knowledge, but to apply internally.

\section{Hypotheses Development Relative to Translating Knowledge into Global Business}

\section{Strategies}


Our research in this section explores knowledge management to specific strategic configurations that MNCs will use in a transitional market. Past foundational research in international management has identified several attributes of global competitive advantage, such as firm- and location-specific advantages (Kogut, 1985), integration of functional area (Porter, 1986), etc. Current knowledge management literature does focus on subsidiary level knowledge management (Claver-Cortes, et el., 2018), or from a global human resource management perspective, the role of expatriates in knowledge transfer (Sanchez-Vital, et al., 2018; Vlajčić, et al., 2019). However, very little recent research has focused on the environment-strategy-knowledge management linkage (Cavaliere and Lombardi, 2015).

The strategy literature suggests that organizational learning is important for a company to survive and to attain superior performance (Foss and Pedersen, 2004; Zeng, Grogaard and Steel, 2018). Even successful global MNCs must continue to acquire knowledge that will help them to develop new competencies and to successfully position their product (Peltokorpi and Yamao, 2017; Kogut and Mello, 2017). Researchers still know relatively little in regard to how firms acquire useful knowledge much less how this knowledge affects entity performance (Ferraris et al., 2016). Some research suggests that organizational design is important in the learning process as smaller units might accelerate learning (Nadayama, 2018). Market volatility hinders knowledge management as it devalues old knowledge so in transitional economies the importance of successful knowledge management systems becomes imperative. Also, when in uncertain markets where multiple changes occur simultaneously, managers will have difficulty in attributing any particular innovation as the cause of performance change, so strategic configuration to match the environment is of consequence. 


\section{Strategic configurations}

MNC success is attributable to the leveraging of key resources (particularly knowledge) when expanding to new markets (Lin et al., 2014). The rationale for MNC expansion into transitional economies is resultant from the inherent MNC drive for market expansion and the accumulation of new resources. MNC subsidiaries focus on managing the exploitation of existing MNC resources while accumulating local market resources to maximize operational effectiveness. As such, MNCs develop differing strategic configurations for local market effectiveness.

The Miles and Snow strategic choice typology is still considered one of the most used and valuable in strategy literature (Song et al., 2007; Hambrick, 2003). The main reason we use the Miles and Snow typology is due to its industry-independent nature and that it corresponds and changes across multiple industries and countries (Desarbo, et al., 2005). The focus of the typology is that strategies will change to align with local management styles and with the environment of which it operates (Miles and Snow, 1978; Frambach et al., 2016).

There have been a number of typologies in the strategy literature e.g. Miller and Friesen, (1983), Mintzberg (1978), Porter (1985), Miles and Snow (1978), March (1991) that suggest that the external environment influences a firm's strategic configurations. We utilized Miles and Snow's strategic configuration for a number of reasons. The framework has been tested empirically in many studies (e.g. Anwar and Hasnu, 2016, Kald et al., 2000; Lin et al., 2014). The framework combines a number of variables that facilitate investigation in transitional economies; that of human resources, structures and processes (Rajagopalan, 1983). For example, Porter's framework ignores environmental characteristics which is a 
key characteristic we are examining in transitional markets (Segev, 1989). Also we follow recent literature that utilizes this framework: e.g. research explored the strategic types in Poland to performance (Ingram et al., 2016), in the Netherlands in regard to customer orientation and performance (Frambach, Fiss and Ingenbleek, 2016), in China to performance (Luo and Park, 2001), in Saudi Arabia and how culture effects the strategic orientation (Roberston, Yaghmour and Kawther, 2015), how ownership type of a firm in China will be related to the strategic orientation (Peng, Tan and Tong, 2004), how the typology can be more effectively measured by a balanced scorecard in Iran (Khani and Ahmadi, 2012), how pay systems will differ based upon strategic orientation in Finland (Tenhiala and Laamanen, 2018), how the framework can be utilized through a real options approach (Riley, Mau and Hogan, 2016), performance and JVs in China (Luo, Tan and O’Connor, 2001), business ties and strategic orientation in China (Lee, 2018), etc.

As our research concerns knowledge management and strategic configuration in a transitional economy, we utilized the Miles and Snow typology as it has been used in the past for knowledge management (Di Benedetto and Song, 2003). The research suggests that the different strategic configurations will seek and utilize knowledge differently, for example market knowledge of competition and customers will be more important to defenders while prospectors will be more concerned about proactive new product development (McDaniel and Kolari, 1987; DeSarbo, Di Benedetto, Song, and Sinha, 2005).

We will now explore which of the strategies will be most likely chosen by subsidiaries in transitional economies that are characterized by market volatility and uncertainty. The Defender strategy focuses on attempting to maintain a stable environment with a stable form of organization (Slater et al., 2006; 2010). This type of strategy will 
be difficult in transition economies, as the business environment is volatile. Defenders are more successful in stable industries and change does not favor this strategy (Boyne and Walker, 2010). The major risk is the inability to respond to change and shifts in the market environment. The firm will typically have centralized control and does not perform much scanning of the environment for new opportunities. The Defender orientation will have difficulty to adapt in transitional economies due to its uncertain evolving market.

A Reactor strategy is due to three reasons: 1) no clearly articulated strategy, 2) the organization's structure does not match the strategy, and 3) management maintains a strategy-structure despite overwhelming conditions to the contrary (Laugen et al., 2006). Thus, a reactor strategy may exist in transitional economies, but rarely would a subsidiary of an MNC choose such a strategy. The resources that are available to a subsidiary of a MNCs (ex. global management acumen, financial resources, etc.) as well as control mechanisms (ex. reporting to headquarters, knowledge transference, corporate strategy interactions, etc.) would not facilitate a reactor strategy.

Analyzer organizations attempt to take the best attributes of both the Defender and Prospector. This type of organizational strategy maintains their traditional products and customers while seeking new market opportunities and knowledge (Pinto and Curto, 2007). Typically, they utilize a second mover strategy through imitation and apply new products when competitors have shown success. Seeking both technological flexibility and stability, the Analyzer strategy maintains an equilibrium amongst both. The Analyzer should be more efficient as a second mover than the first mover, as it reduces the chances for failure in such an uncertain environment as countries in the transitional stage (Luo and 
Park, 2001). Unfortunately, transitional economies change quickly, and capturing the first mover advantage will be important and the strategic orientation needs to match the environment. Waiting to see what works and then attempting to implement will cause the second mover in such a dynamic environment to fall too far behind to attempt to match a first mover advantage.

Prospectors are very proactive and seek to find new knowledge and market opportunities, which creates a reputation as an innovator in product and market development at the expense of profitability (Slater et al., 2010). To do this the firm must constantly be scanning the environment to obtain knowledge to locate and develop product and market opportunities. The Prospector strategy will be chosen for two reasons by an MNC subsidiary: it has the resources to do so, and for global knowledge management. MNCs will have the resources (ex. Financing, personnel, R\&D, etc.) to allocate to their subsidiaries to dominate the local transitional marketplace. These global firms will be more interested in developing the market for the long-run than for short-term profitability. Also, this strategic orientation will facilitate knowledge management as multiple, prototypical technologies and administrative flexibility is one of its characteristics.

\section{$H_{1}: \quad$ For knowledge management purposes MNCs will choose the Prospector strategy more often than any other strategy in a transition economy.}

\section{The Influence of Strategy on Knowledge Management Capabilities}

For MNCs to be successful they must simultaneously be utilizing their existing knowledge while seeking and applying new knowledge (Gold, et. al., 2001). Management of internal as well as external knowledge is an integral part of the knowledge management process (Feraris et al., 2017). Past research suggests that there are similar aspects that are necessary for the knowledge management process to be successful in the transition 
economies (e.g. create, transfer, use (Skyrme and Amidon, 1998; Kiessling et al. 2009; Ferrri et al., 2018), capture, transfer, use (DeLong, 1997)). The three elements of knowledge management capabilities can be viewed as: 1) knowledge acquisition, 2) knowledge conversion, and 3) knowledge application (Gold, et al., 2001). Acquisition-oriented knowledge management

Acquisition-oriented knowledge management refers to those processes oriented toward the obtainment of knowledge (Gold et al. 2001). Inherent in the conceptualization of the acquisition of knowledge is the accumulation of knowledge (Gold et al. 2001; Sinkula et al., 1997). The acquisition of knowledge requires more than simply the sharing and collaboration of experiences, but also requires the organization to be able identify its importance, or lack there-of (Burmeister et al., 2018). Knowledge must be actively sought and converted and the firm must develop a strategic competency to do so (Harzing et al., 2016). Thus, the strategic orientation of an organization is theorized to be related to firm's employment of acquisition process of knowledge management.

Acquisition of knowledge for the Defender requires new knowledge for the purposes of changing or refining a firm's current products or processes (Wilden et al., 2018). The Defender will only have a limited knowledge acquisition process as the focus is on technological efficiencies. Acquisition of knowledge for the Prospector is very active as the management processes are developed towards obtaining new knowledge related to the competitive environment and the Prospector invests heavily in individuals and groups who scan the environment for potential opportunities (Wilden et al., 2018). The knowledge management acquisition process for Reactors is moderate without concerted efforts or a high a degree of experience in recognizing and capturing new knowledge. The Analyzer which 
is a combination of Defender/Prospector will defend their product markets but also needs to react quickly to new products and innovations. This forces the Analyzer to split its resources, not focusing upon acquisition of new knowledge as much as the Prospector.

\section{Conversion-oriented knowledge management}

Conversion-oriented knowledge management processes refer to those processes oriented towards making existing knowledge useful (Gold et al. 2001). The underlying processes of conversion-oriented knowledge management processes include a firm's ability to organize, integrate, coordinate and disseminate knowledge (Andreeva and Ikhilchik, 2011). The conversion-oriented knowledge management process is easy in regard to explicit knowledge of statistics, numbers, percentages, etc., but becomes difficult due to the complicated local/global context of the information (Sheng et al., 2015). This research directly emphasizes that the knowledge conversion process is related to the strategic orientation of the firm.

The centrally controlled Defender orientation focuses on efficiencies afforded by economies of scale and scope. To achieve efficiencies, the knowledge conversion process that is developed is hierarchal, centrally controlled, cumbersome and slow (Desarbo et al., 2005). The Prospector's organizational framework is decentralized with very flexible knowledge sharing (vertical and horizontal) which assists in the knowledge conversion process (Boulianne, 2007). As a Prospector organization is driven towards knowledge acquisition, centralized bureaucratic structures and processes will not be present to create internal barriers in the ability to transfer knowledge, present in most MNCs or subsidiaries (Kearns, 2006; Barrios et al., 2012). Although research suggests that the Reactor strategy can be successful, often the conversion of new knowledge is hindered due to being 
misunderstood as there is little common dialogue, and integration becomes difficult. The Analyzer's conversion of the acquired knowledge is through a complex matrix structure that balances the exploitation of firm-specific competitive advantages and exploration of host country-specific comparative advantages (Blumentritt and Danis, 2006). The dual nature of the Analyzer (maintaining a Defender position and a Prospector strategy) encourages firms to minimize the active seeking of new knowledge in an uncertain transitional economy.

\section{Application-oriented knowledge management}

Application-oriented knowledge management processes refer to those processes oriented toward the utilization of knowledge (Gold et al., 2001). Application-oriented knowledge management processes include the storage, retrieval, application, contribution and sharing of knowledge (Almeida 1996; Appleyard 1996; Gold et al. 2001). Effective storage and retrieval processes allow a firm to efficiently and effectively access knowledge for its application.

Utilizing the Defender's orientation, a top management team can incorporate new knowledge into technologies and is the most important part of the knowledge management as effective application of knowledge helps companies to improve their efficiency and reduce costs (Boyne and Walker, 2010). The application of knowledge for the Prospector is such that the entrepreneurial projects take precedence in the allocation of resources, as this is the Prospector's major strategic focus (Kabanoff and Brown, 2008). Reactors do not effectively apply any knowledge acquired to improve their efficiency and reduce costs. Analyzers key focus in transitional economies is the application of knowledge is to both maintain status quo 
while tailoring products to meet the value proposition within the market. The applicationbased processes are those oriented toward the actual use of the knowledge (Gold et al., 2001).

Research has suggested that knowledge management could be effective in transitional economies (Ingram et al., 2016). Knowledge management has two components: using knowledge that is closely related to their preexisting knowledge basis (Stuart and Podolony, 1996) and exploratory search behaviors in a conscious effort to move away from preexisting knowledge basis and organizational routines (Miner et. al., 2001). The Analyzer focuses on defending existing product markets through routine, efficient operations (Defender) while quickly reacting to competitor's new product success and innovations (Prospector). Previous research suggests that this duality forces the Analyzer to acquire knowledge in the emerging marketplace to locate new market opportunities and to respond to the market while maintaining a firm core of traditional products (Luo and Park, 2001; Cui et al., 2006). However, as this environment requires new products, processes, and unique entrepreneurial skills are required, Prospectors should be the greatest pursuers' of knowledge. This becomes important for MNCs who are organic in nature and are orchestrating global knowledge management. Therefore, we propose:

$$
\begin{aligned}
& \boldsymbol{H}_{2}: \quad \begin{array}{l}
\text { MNCs utilizing the prospector strategy will pursue knowledge } \\
\text { management in transitional economies more so than any other } \\
\text { strategy. }
\end{array}
\end{aligned}
$$

\section{Knowledge Management and Performance in Transitional Markets}

Although there is some research that suggests knowledge management does affect firm performance positively, our research wishes to explore knowledge management in the context of transitional markets to firm performance. Our research explores the Miles and Snow's (1978) typology initially from a knowledge management perspective but past 
research suggest that all four strategic types have very little variance in regard to firm performance (e.g., Miles, Snow and Sharfman, 1993; Snow and Hambrick, 1980; Smith, Guthrie, and Chen, 1986). An incumbent firm may be pursuing a Defender strategy and be successful if they have a good knowledge management system, MNCs entering the market may utilize the prospector strategy and if they have a good knowledge management system will have good performance, etc. (e.g., McKee, Varadarajan, and Pride, 1989). Hence, our contribution is a direct relationship to knowledge management and performance in transitional markets. However, we still wish to explore whether strategic orientation affects firm performance in transitional economics.

Research on the business strategies (Prospector, Analyzer, Defender, Reactor) have shown that all four perform equally well (Slater and Olson, 2000; Desarbo et al., 2005). The variations in performance occur due to the implementation of the strategy, and a key variable maybe the success or failure of their knowledge management systems. Therefore, organizations following a particular strategy must make sure that they actually follow the strategy's prescriptions and be consistently applied by management (Sallee and Flaherty, 2003). A firm needs to align its internal processes, such as their knowledge management systems, with its business strategy in its efforts to sustain competitive advantage (Ingram et al., 2016). The typology is important for researchers as this is a view of organizations as completely integrated dynamically interacting with the external industry (Desarbo et al., 2005).

Therefore our focus in this research is the knowledge management practices of firms, as past research suggests that knowledge management may be performance enhancing (Inkinen, 2016), as innovation performance increases (Donate and de Pablo, 
2015), the arts and crafts industry had better performance with knowledge management (Manfredi et al., 2018), and knowledge management in Italian firms produce greater performance (Giampaoli et al., 2017). Effective learning appears to be cumulative in nature and development of new knowledge in international markets is important for good performance (Nonaka and Takeuchi, 1995; Bartlett and Ghoshal, 1987).

The knowledge that is locally obtained especially in transition uncertain economies influences the ability of a firm to: adapt products to local product markets, identify technological changes that affects firm performance, and capitalize on market dynamism through new product developments (Afuah, 1998, McCann, 1991; Ghoshal, 1987; Ghoshal, and Bartlett, 1990). Knowledge acquisition can come from the direct experiences of the organization and its members, so effective knowledge management (acquisition, conversion, and application) should provide greater performance (Lyles, 1994). We therefore theorize:

H3: Knowledge management will positively affect subsidiary performance in transitional economies.

Our research hypotheses suggest that MNC subsidiaries will utilize the Prospector strategy in transitional marketplaces. This is due to the requirement to seek and exploit knowledge management opportunities in a dynamic ever-changing marketplace. To continue the literature stream, we also propose that firms pursuing the Prospector strategy will have greater subsidiary performance.

H3a: Firms utilizing the Prospector strategy in transitional economies will have greater performance. 


\section{Sample}

Our ultimate sample was 131 foreign MNC subsidiaries located in Croatia. Our sample came from the FDI data which totaled 500 firms, but after incomplete questionnaires were deleted, we had 125 responses that were useable. We reduced the 500 firms to the top $300 \mathrm{MNCs}$ who had the largest amount of FDI. We contacted the 300 firms with mailed questionnaires, and multiple follow-up phone calls and e-mails. Subsequently, 131 (43.7\% response rate) responded. Our sample had firm average number of employees as 1075, firm average years of international experience as 20 , with a vast range of industries (ex. agricultural, biotech, chemical, electric equipment, leather, naval technology, plastics, printing, rubber manufacturing and electronics). The respondents average age was 41 , with 14 years of international experience, representing firms with over \$1 million in average annual sales. In regard to the respondents' level of seniority; $27 \%$ were senior executives (e.g., Vice-President level or above) and $73 \%$ were senior managers. In regard to gender our ratio was $54 / 46 \%$ male/female.

\section{Pre-test}

We utilize past existing measures for all our variables that were from English speaking journals so initially develop the questionnaire in English. Accordingly, we pretested our survey instrument with English speaking international market researchers, and business professionals. We then translated the questionnaire through an external translator and back-translated by committee (cf., Brislin 1970; Sperber et al., 1994). When required we made minor adjustments to the survey instrument so the Croatian translation was appropriate (cf., Sperber et al. 1994). 


\section{Measures}

Our strategic orientation was developed by utilizing Miles and Snow's (1978) typology of strategy. We used four descriptive paragraphs describing each of the strategies (Defender, Reactor, Analyzer, Prospector) in line with previous research (Snow and Hrebiniak, 1980; Lukas, 1999). Upon reading the descriptive paragraphs of each strategic orientation, our sample respondents, were asked to select one when they compared themselves to other firms in the industry.

From the foundation literature of knowledge management, our variables were based upon the three underlying dimensions, i.e., knowledge acquisition, knowledge conversion, and knowledge application (Gold et al. 2001). See Exhibit 1 for the items on the instrument. All were assessed on a 7 point, Likert-type scale derived from Gold et al. (2001).

----------Insert Exhibit 1----------

The hypothesized factor structure and parameter estimates are provided in Table 1. The model as a whole has satisfactory fit to the data (Chi-squared, p, GFI, RMSR, NFI, IFI), and the relevant first- and second-order factor loadings are large and significant. In sum, the model lends support to the conceptualization of knowledge management as a second order construct. Hence, the three dimensions of knowledge management were combined into an equally weighted composite score for hypothesis tests (cf., Heide and John 1992). We use factor analysis in Table 1 to show the second-order latent factor structure of knowledge management. After proving this structure, we simply take the average of 3 sub-dimensions of it, to enter into the regression models -to test our 
hypotheses. In essence we created a composite score of three sub-dimensions with equal weights.

\section{Insert Table 1 about here}

Performance was conceptualized as consisting of both internal and competitive dimensions. Following Jaworski and Kohli (1993) performance was measured via a twoitem scale assessing whether (1) the firms' overall performance last year was greater than expected and (2) the firm outperformed its major competitors in the last year. The correlation coefficient for the scale was .78.

Market dynamism consists of business practices that are occurring locally as well as how the local environment is changing. Utilizing past measures measuring market dynamism we used a 2-item, 7 point, Likert-type scale (Jap, 1999). Please see exhibit 1 for the items on the instrument. The correlation coefficient for the scale was .75.

To measure competitive intensity, we utilized past research to ascertain the environment's level of uncertainty and dynamism (Grewal and Tansuhaj, 2001; Jaworski and Kohli, 1993). The 4-item, 7-point Likert-type scale assessed competitive intensity based upon promotional wars, new competitive moves, general competitions and price competition. Coefficient alpha for the scale was .90 .

\section{Control Variables}

Research suggests that firm size (measured as number of employees) would interact with a firm's knowledge management capabilities both positively and negatively, so controlled for firm size. Large firms will have superior resources and can organize according to the development of knowledge management (acquisition and conversion). 
However, large firms, due to this bureaucracy, may be limited in their ability to apply knowledge. Smaller firms with have less resources (both human and systems) to have a superior knowledge management system that acquires and converts knowledge, but may be able to apply knowledge quickly due to the lack of bureaucracy and channels.

Our final two control variables used in past research is industry and length of operations. Past research indicates that industry will directly affect knowledge management capabilities and controlled for industry (Hitt and Ireland, 1985). According to past research the MNC subsidiaries were classified as consumer durable, consumer nondurable, capital, and producer. The last control variable is the length of operations in international business of the subsidiary. The years in operating in a global business environment will affect the reasons for acquisition and the knowledge management system development as subsidiaries. Newly formed subsidiaries may lack the knowledge management capabilities to be effective within a MNC.

\section{Analysis and Results}

Table 2 presents the descriptive statistics and Pearson correlation coefficients for the study variables. We also ran four tests for heteroscedasticity: Levene's test, histogram, normal P-P plot of regression standardized residual, and a scatterplot. Upon review of these empirical tests and that Levene's test of the null hypothesis of equal variances is rejected we conclude that there is a difference between the variances in the population. As expected, MNC subsidiary managers perceived the Croatian market to be dynamic ( $\bar{X}=4.60)$ and highly competitive $(\bar{X}=5.04)$. The correlation matrix (where each strategic orientation is coded as 0,1 ) shows a moderate positive association between the Prospector orientation and the environmental dimensions $\left(\mathrm{r}_{\mathrm{MD}}=.437, \mathrm{r}_{\mathrm{CI}}=.369\right)$. The 
Defender and Reactor orientations were found to be negatively associated to both market dynamism and competitive intensity $\left(\mathrm{r}_{\mathrm{MD}}=-.233, \mathrm{r}_{\mathrm{CI}}=-.196, \mathrm{r}_{\mathrm{MD}}=-.296, \mathrm{r}_{\mathrm{CI}}=-.359\right.$, respectively). Further, the Analyzer orientation was not found to be significantly associated with either market dynamism or competitive intensity.

\section{Insert Table 2 about here}

H1 states that successful MNCs will use a Prospector strategy in transitional economies. Our discriminant analysis analyzed the environment and strategic orientations constructs. Our results are highly significant (see Table 3): overall Wilks' lambda was significant $\left(\Lambda=.72, \chi^{2}(6,124)=38.88, \mathrm{p}<.001\right)$, indicating that the predictors of the four strategic orientations were differentiated. Table 3 presents the within-group correlations between the predictors and the discriminant function as well as the standardized weights. All results indicate that the discriminant function is consistent. The Prospector orientation had the highest mean scores $(\bar{X}=.723)$ followed by Analyzers ( $\bar{X}=-.125)$, Defender $(\bar{X}=-.666)$ and Reactor $(\bar{X}=-.749)$ orientations. The results support $\mathrm{H} 1$ and the relationship proposed.

\section{Insert Table 3 about here}

To test the theoretical correlation between knowledge management capabilities and strategic orientation we used the ANCOVA method and controlled for industry, years in international business and firm size. $\mathrm{H} 2$ suggests that the prospector strategy will pursue knowledge management in transitional economies more so than any other strategy. Our results suggest discriminant validity as show in Table 4 in knowledge management 
capabilities across strategic orientations $\left(\mathrm{F}=6.001, \mathrm{df}=3 / 67, \mathrm{p}=.001, \eta^{2}=.212\right)$. The results also indicate that the control variables were not significant: firm size $(\mathrm{F}=.395, \mathrm{df}=1 / 67$, $\mathrm{p}=.523)$; number of years of international operations $(\mathrm{F}=1.510, \mathrm{df}=1 / 67, \mathrm{p}=.223)$; industry $(\mathrm{F}=.655, \mathrm{df}=1 / 67, \mathrm{p}=.421)$.

\section{Insert Table 4 and 5 about here}

Furthering our methodology, we performed post hoc tests with ANOVA on strategic orientation and knowledge management capabilities. Our results were significant $\left(\mathrm{F}=12.756, \mathrm{df}=3 / 108, \mathrm{p}<.001, \eta^{2}=.262\right)$ suggesting that the Prospector orientation was most highly correlated with knowledge management capabilities in relation to the 3 other strategic orientations Analyzer $\left(\bar{X}_{\text {P-A }}=.9822, \mathrm{p}<.002\right)$, Defender $\left(\bar{X}_{\text {P-D }}=1.785, \mathrm{p}<\right.$ $.001)$ or Reactor $\left(\bar{X}_{\mathrm{P}-\mathrm{R}}=1.454, \mathrm{p}<.001\right)$. We also performed Tukey analysis to examine the difference across groups.

Next, regression analysis was used to test the relationship between knowledge management capabilities and performance theorized in $\mathrm{H}_{3}$. To minimize spuriousness of results, the previously mentioned covariates were incorporated into the regression analysis. Results indicate that the knowledge management capability is strongly associated with firm performance $(B=.521, \mathrm{t}=5.037, \mathrm{p}<.000)$. The covariates of firm size $(B=.008, \mathrm{t}=076, \mathrm{p}=.940)$, years of international experience $(B=.003, \mathrm{t}=031, \mathrm{p}=.975)$ and industry $(B=.036, \mathrm{t}=357, \mathrm{p}=.722)$ were found not to significantly influence performance.

Overall, the regression equation explains $27.0 \%$ of the variation in firm performance. The results support the theorized relationship between knowledge management capabilities and firm performance as presented in $\mathbf{H}_{3}$. 
We performed mean plot comparison analysis and found that the Prospector strategy performed better than the other three strategic configurations. We then ran a Tukey analysis for significance between the different strategic configurations. We found significance between the Prospector to Defender and Reactor in regard to strategic orientation and performance, however, although the plot in Table 6 suggests greater performance than that of the Analyzer, the Tukey test did not suggest a significant difference. Hence, though $\mathrm{H} 3 \mathrm{a}$ has some support, statistically H3a is rejected.

---------Insert Table 6 and 7 about here------------

\section{Discussion and Conclusion}

As theorized, and empirically supported, in this study, Prospectors in the transitional economy of Croatia develop advanced knowledge management capabilities, inclusive of knowledge acquisition, conversion and application, to allow them to more appropriately exploit opportunities in the highly uncertain and dynamic environment. Through the development of knowledge management capabilities Prospectors are able to optimize resource investments while coordinating efficiently and effectively with their MNC. The ability of MNC subsidiaries to capitalize on market opportunities requires that the MNC subsidiary have effective knowledge management capabilities.

Past research has suggested that knowledge management will be required in transitional economies (Ingram et al., 2016) due to the ever-changing nature of the consumer and institutions such as found in Croatia; which has the greatest of all strategic changes of the CEECs (Stoicic, Hashi and Telhai, 2011). The Prospector strategy seeks to find new knowledge and develops a brand image as an innovator, which will be 
especially important in a transitional economy whereby new products are entering the market and consumer demands are changing quickly (Slater et al., 2010).

The Prospector strategy will be required to utilize existing knowledge while seeking new knowledge to be successful (Gold et al., 2001). This will require employees, who may still be influenced by the previous socialist-type marketplace, to be trained as to how to manage knowledge from both an internal as well as external viewpoint (Feraris et al, 2017; Andreeva and Kianto, 2012). Much of this knowledge may be tacit knowledge (non-codifiable embedded within an individual) and organizations will be required to develop internal systems to transfer this knowledge (Klafke et al., 2016). Identification of external knowledge and then the development of systems, starts first from employee identification and then transmission throughout the firm to leverage innovation and to create superior firm performance (Ferraresi et al., 2012; Lee, Kim and Kim, 2011).

Miles and Snow's framework has been used to explore knowledge management in the past (Di Benedetto and Song, 2003) and our research utilized this framework in a transitional marketplace to ascertain which strategic orientation would be more successful as knowledge management enablers and processes create better firm performance (Mills and Smith, 2010). Knowledge management capabilities of a subsidiary MNC will not only be established to focus on the local market, but must also have a global viewpoint as crossborder flows will also impact the local subsidiary (Gaur, Ma and Ge, 2019). Hence the local subsidiary must have a comprehensive knowledge management structure to absorb new knowledge from many different arenas (ex. Local, global, individual, etc.) and to be able to apply quickly. Our research, in accordance with past research, suggests that the Prospector strategy is the best to perform this function. 
Clearly there is substantial interaction between the MNC subsidiary's environment and the MNC subsidiary's strategic orientation. Most notably, the environment studied here was at the competitive and consumer market level. As more firms in the marketplace adopt a Prospector orientation, market development becomes accelerated. For example, as more firms in a market engage in a prospector orientation they continually strive to introduce new products into the market. As such, individual product lifecycles become shorter as newer products are introduced into the market. Existing products are pushed from the growth stage to the maturity stage of the product life cycle, enhancing the overall competitive intensity due to reduced margins. At the same time, the introduction of new products not influences consumer demands that can significantly alter business practices. As such, strategy may not only be enacted based upon the perceived environment, but the enactment of strategy influences the environment.

Our research explored knowledge management capabilities and the resultant performance and found that firms in transitional economies with superior knowledge management systems will have greater performance. Our research suggested that the prospector strategy would the most used to attain these knowledge management systems, so also explored if the prospector strategy would also illustrate the highest firm performance. Past research suggests that all four strategies will have good performance, as that is why a particular firm chose that strategy (e.g., Miles, Snow and Sharfman, 1993; Snow and Hambrick, 1983; Smith, Guthrie, and Chen, 1986), but we wanted to explore if this was true in a dynamic transitional marketplace. Our empirical results suggest that the prospector strategy was superior to the other three strategies in regard to performance (although only statistically significant to that of the defender and reactor strategies). These 
findings are intuitive as a prospector strategy will develop superior knowledge sharing routines that will provide superior performance (Youssef, Haak-Saheem and Youssef, 2017).

\section{Managerial Implications}

The managerial implications to our research are numerous. MNCs must change their strategic configuration based upon the local market conditions to successfully compete. Each market has differing institutions and consumer tastes, and MNCs must determine the strategic configuration that not only can focus on the local environment, but also fit into their global strategy. To facilitate the strategic orientation, knowledge management systems must be an important ingredient and be incorporated into the structure. In transitional economies, these knowledge management systems become even of more import, as the dynamic environment of the marketplace makes knowledge acquisition, conversion and implementation a critical component.

As such, knowledge management requires employees with the training and acumen to identify important knowledge. Often this knowledge may be tacit and embedded within individuals. Transitional market employees often still have a disposition that is not conducive for knowledge transference, and MNC subsidiaries need to be aware that managers must create an atmosphere of trust and encouragement for new ideas and innovative tactics.

\section{Limitations and Future Research:}

Our research focused on the transitional marketplace of Croatia as the setting, and although many aspects may be generalizable to other transitional economies, each country has different institutional norms, culture, and historical precedence. For example, Stojcic, 
Hashi and Telhaj's (2011) research explored Central and Eastern European Countries (CEECS) (i.e. the Czech Republic, Slovakia, Poland, Bulgaria and Croatia) and found many differences amongst the countries. For example, labor efficiency amongst the countries was illustrated to be statistically significant, which will directly affect performance, regardless of knowledge management practices.

In regard to knowledge management, there are so many units of analysis, that focusing on any particular country may cause difficulty in generalizability. For example, there is the local management and their aptitude (such as global experience, education, experience, etc.), the MNC themselves (ex. Years' experience, size, globalization, implementation of previous knowledge management systems, brand name, mode of market entry, etc.), as well as the country variables (ex. Scale of development, institutional factors, governmental issues and changes in policies, etc.). Although impossible to control for all prevailing variables, researchers will need to attempt to incorporate as many as possible in their models.

Another limitation to our study may be the use of Miles and Snows' model in a transitional economy. Although the model has been tested successfully over a long period of time, most of the research was focused in developed countries. Although we have seen the model now applied throughout the world (ex. Ingram et al., 2016; Frambach, Fiss and Ingenbleek, 2016; Luo and Park, 2001; Roberston, Yaghmour and Kawther, 2015; Peng, Tan and Tong, 2004), the international business research field has suggested that many models and theoretical foundations developed in developed-markets may not be applicable to developing or transitional countries, and either new theories, or a mixture of theories, may need to be applied to explain phenomena. 


\section{References}

Afuah, A. (1998), Models of innovation. Innovation Management: Strategies, Implementation, and Profits. New York: Oxford University Press, 13-45.

Almeida, P. (1996), Knowledge sourcing by foreign multinational: Patent citation analysis in the U.S. semiconductor industry. Strategic Management Journal, 17(S2), 155165.

Andreeva, T. and Ikhilchik, I. (2011),. Applicability of the SECI model of knowledge creation in Russian cultural context: theoretical analysis. Knowledge and Process Management, 18(1), 56-66.

Andreeva, T., \& Kianto, A. (2012). Does knowledge management really matter? Linking knowledge management practices, competitiveness and economic performance. Journal of knowledge management, 16(4), 617-636.

Anwar, J., \& Hasnu, S. A. F. (2016). Business strategy and firm performance: a multiindustry analysis. Journal of Strategy and Management, 9(3), 361-382.

Appleyard, M.M. (1996), How does knowledge flow? Interfirm patterns in the semiconductor industry. Strategic Management Journal, 17(S2), 137-154.

Aragon-Sanchez, A and Sanchez-Main, G (2005), Strategic orientation, management characteristics, and performance: A study of Spanish SMEs. Journal of Small Business Management 43(3): 287-308.

Barrios, S., Huizinga, H., Laeven, L. and Nicodème, G. (2012), International taxation and multinational firm location decisions. Journal of Public Economics, 96(11-12), 946-958.

Blomkvist, K. (2012), Knowledge management in MNCs: the importance of subsidiary transfer performance. Journal of Knowledge Management, 16(6), 904-918.

Boulianne, E. (2007), Revisiting fit between AIS design and performance with the analyzer strategic-type. International Journal of Accounting Information Systems, 8(1), 1-16.

Blumentritt, T. and Danis, W. M. (2006), Business strategy types and innovative practices. Journal of Managerial Issues,18 (2) 274-291.

Boyne, G. A. and Walker, R. M. (2010), Strategic management and public service performance: The way ahead. Public administration review, 70, s185-s192.

Brislin, R. W. (1970), Back-translation for cross-cultural research. Journal of crosscultural psychology, 1(3), 185-216. 
Burmeister, A., Lazarova, M. B. and Deller, J. (2018), Repatriate knowledge transfer: Antecedents and boundary conditions of a dyadic process. Journal of World Business, 53(6), 806-816.

Cadogan, J. W., Kuivalainen, O., \& Sundqvist, S. (2009), Export market-oriented behavior and export performance: quadratic and moderating effects under differing degrees of market dynamism and internationalization. Journal of international Marketing, 17(4), 71-89.

Cavaliere, V. and Lombardi, S. (2015), Exploring different cultural configurations: how do they affect subsidiaries' knowledge sharing behaviors?. Journal of Knowledge Management, 19(2), 141-163.

Chiao, Y. C., Yu, C. M. J., Li, P. Y., \& Chen, Y. C. (2008). Subsidiary size, internationalization, product diversification, and performance in an emerging market. International Marketing Review, 25(6), 612-633.

Claver-Cortés, E., Zaragoza-Sáez, P., Úbeda-García, M., Marco-Lajara, B., \& GarcíaLillo, F. (2018), Strategic knowledge management in subsidiaries and MNC performance. The role of the relational context. Journal of Knowledge Management, 22(5), 1153-1175.

Coad, A., Daunfeldt, S., Ho“lzl, W., Johansson, D.,\&Nightingale,P. (2014). High-growth firms: Introduction to the special section. Industrial and Corporate Change, 23(1), 91-112.

Crespo, C. F., Griffith, D. A., \& Lages, L. F. (2014), The performance effects of vertical and horizontal subsidiary knowledge outflows in multinational corporations. International Business Review, 23(5), 993-1007.

Cui, A. S., Griffith, D. A., Cavusgil, S. T and Dabic, M. (2006). The influence of market and cultural environmental factors on technology transfer between foreign MNCs and local subsidiaries: A Croatian illustration. Journal of World Business, 41, 100111

Dabic, M., \& Bach, P. (2008). Understanding the foreign direct investment environments in EU 27+ candidate country Croatia: the current determinants and patterns. International Journal of Entrepreneurship and Innovation Management, 8(3), 254-271.D

Dabić, M., Daim, T. U., Aralica, Z., \& Bayraktaroglu, A. E. (2012), Exploring relationships among internationalization, choice for research and development approach and technology source and resulting innovation intensity: Case of a transition country Croatia. The Journal of High Technology Management Research, 23(1), 15-25. 
DeSarbo, W. S., Anthony Di Benedetto, C., Song, M. and Sinha, I. (2005), Revisiting the Miles and Snow strategic framework: uncovering interrelationships between strategic types, capabilities, environmental uncertainty, and firm performance. Strategic management journal, 26(1), 47-74.

Di Benedetto, C. A., \& Song, M. (2003). The relationship between strategic type and firm capabilities in Chinese firms. International Marketing Review, 20(5), 514-533.

Donate, M. J. and de Pablo, J. D. S. (2015), The role of knowledge-oriented leadership in knowledge management practices and innovation. Journal of Business Research, 68(2), 360-370.

Ensign, P. C., Birkinshaw, J. M. and Frost, T. S. (2000), R\&D centres of excellence in Canada.In U. Holm \& T. Pedersen (Eds.),The emergence and impact of MNC Centres of excellence: A subsidiary perspective . London, UK: Macmillan Press

Ernst and Young (2017) E\&Y Attractiveness Survey, Europe. https://www.ey.com/Publication/vwLUAssets/EY_Attractiveness_Survey_2017/ \$FILE/EY-Attractiveness-Survey\%20Europe-2017.pdf

Ferraris, A., Santoro, G., and Dezi, L. (2017), How MNC's subsidiaries may improve their innovative performance? The role of external sources and knowledge management capabilities. Journal of Knowledge Management, 21(3), 540-552.

Ferraris, A., Santoro, G., \& Scuotto, V. (2018). Dual relational embeddedness and knowledge transfer in European multinational corporations and subsidiaries. Journal of Knowledge Management. https://doi.org/10.1108/JKM-09$\underline{\text { 2017-0407 }}$

Ferreira, M. P., Pinto, C. F., \& Serra, F. R. (2014), The transaction costs theory in international business research: a bibliometric study over three decades. Scientometrics, 98(3), 1899-1922.

Ferraresi, A. A., Quandt, C. O., dos Santos, S. A., \& Frega, J. R. (2012). Knowledge management and strategic orientation: leveraging innovativeness and performance. Journal of knowledge management, 16(5), 688-701.

Foss, N. J., \& Pedersen, T. (2004), Organizing knowledge processes in the multinational corporation: An introduction. Journal of International Business Studies, 35(5), 340-349.

Frydman, R., Hessel, M. and Rapaczynski, A. (1998), Why ownership matters?: Politicization and entrepreneurship in the restructuring of enterprises in Central Europe (Vol. 14). New York University, Faculty of Arts and Science, Department of Economics. 
Frambach, R. T., Fiss, P. C. and Ingenbleek, P. T. (2016), How important is customer orientation for firm performance? A fuzzy set analysis of orientations, strategies, and environments. Journal of Business Research, 69(4), 1428-1436.

Gaur, A. S., Ma, H., \& Ge, B. (2019). MNC strategy, knowledge transfer context, and knowledge flow in MNEs. Journal of Knowledge Management.

Gold, A. H., Malhotra, A., \& Segars, A. H. (2001). Knowledge management: An organizational capabilities perspective. Journal of Management Information Systems, 18(1), 185-214.

Ghoshal, S. (1987). Global strategy: An organizing framework. Strategic Management Journal, 8(5), 425-440.

Ghoshal, S. and Bartlett, C. A. (1990). The multinational corporation as an interorganizational network. Academy of management review, 15(4), 603-626.

Giampaoli, D., Ciambotti, M. and Bontis, N. (2017), Knowledge management, problem solving and performance in top Italian firms. Journal of Knowledge Management, 21(2), 355-375.

Grewal, R. and Tansuhaj, P. (2001), Building organizational capabilities for managing economic crisis: The role of market orientation and strategic flexibility. Journal of marketing, 65(2), 67-80.

Hambrick, D. C. (2003), On the staying power of defenders, analyzers, and prospectors. Academy of Management Perspectives, 17(4), 115-118.

Harzing, A. W., Pudelko, M. and Sebastian Reiche, B. (2016), The bridging role of expatriates and inpatriates in knowledge transfer in multinational corporations. Human Resource Management, 55(4), 679-695.

Heide, J. B. and John, G. (1992), Do norms matter in marketing relationships?. Journal of marketing, 56(2), 32-44.

Hong, J. F. and Snell, R. S. (2015), Knowledge development through co-opetition: A case study of a Japanese foreign subsidiary and its local suppliers. Journal of World Business, 50(4), 769-780.

Hitt, Michael A. and R. Duane Ireland (1985), "Strategy, Contextual Factors and Performance," Human Relations, 38(8), 793-812.

Inkinen, H. (2016), Review of empirical research on knowledge management practices and firm performance. Journal of Knowledge Management, 20(2), 230-257.

Ingram, T., Kraśnicka, T., Wronka-Pośpiech, M., Głód, G., \& Głód, W. (2016), Relationships between miles and snow strategic types and organizational 
performance in polish production companies. Journal of Management and Business Administration, 24(1), 17-45.

INSEAD (2019) The Global Talent Competitiveness Index 2019

https://www.insead.edu/sites/default/files/assets/dept/globalindices/docs/GTCI-2019-

Report.pdf

Jap, Sandy D. (1999), "Pie-Expansion Efforts: Collaboration Processes in Buyer-Seller Relationships," Journal of Marketing Research, 36(4), 461-475.

Jaworski, Bernard J. and. Kohli, Ajay K. (1993), "Market Orientation: Antecedents and Consequences," Journal of Marketing, 57(3), 53-70.

Kabanoff, B. and Brown, S. (2008), Knowledge structures of prospectors, analyzers, and defenders: Content, structure, stability, and performance. Strategic Management Journal, 29(2), 149-171.

Kald, M., Nilsson, F., \& Rapp, B. (2000). On strategy and management control: the importance of classifying the strategy of the business. British Journal of Management, 11(3), 197-212.

Kearns, C. C. (2006), State Implementation of the Suta Dumping Prevention Act of 2004. . \& Loc. Tax Law., 11, 105.

Khani, A., \& Ahmadi, M. (2012). Performance measurement using balanced scorecard measures and strategy based on Miles and Snows typology in Iran. African Journal of Business Management, 6(46), 11391-11400.

Kiessling, T. S., Richey, R. G., Meng, J. and Dabic, M. (2009), Exploring knowledge management to organizational performance outcomes in a transitional economy. Journal of World Business, 44(4), 421-433.

Kirca, A. H. and Tomas M. Hult, G. (2009a), Intra-organizational factors and market orientation: effects of national culture. International Marketing Review, 26(6), $633-650$.

Kirca, A. H., Cavusgil, S. T., \& Hult, G. T. M. (2009b), The effects of national culture on market orientation: Conceptual framework and research propositions. International Business Review, 18(2), 111-118.

Klafke, R. V., Lievore, C., Picinin, C. T., de Francisco, A. C., \& Pilatti, L. A. (2016). Primary knowledge management practices applied in Brazil, Russia, India and China (BRIC) industries from 2001-2010. Journal of Knowledge Management, 20(4), 812-828. 
Kogut, B. (1985). Designing global strategies: Comparative and competitive valueadded chains. Sloan Management Review (pre-1986), 26(4), 15.

Kogut, C. S., \& Mello, R. C. D. (2017). Reverse knowledge transfer in multinational companies: A systematic literature review. BAR-Brazilian Administration Review, 14(1).

Kogut, B. Zander, U.(1992), Knowledge of the Firm, Combinative Capabilities, and the Replication of Technology, Organization Science, 3, 1992, pp. 384-397.

Kogut, B. Zander, U. (1993), Knowledge of the firm and the evolutionary theory of the multinational corporation. Journal of International Business Studies, 24(4), 625646.

Krasniqi, B. A., \& Desai, S. (2016). Institutional drivers of high-growth firms: countrylevel evidence from 26 transition economies. Small Business Economics, 47(4), 1075-1094.

Laugen, B. T., Boer, H. and Acur, N. (2006), The new product development improvement motives and practices of Miles and Snow's prospectors, analysers and defenders. Creativity and innovation management, 15(1), 85-95.

Lee, P. Y. (2019). Taking a prospector local-market focus and foreign subsidiary performance: evidence from China. Management Decision, 57(3), 569-582.

Lee, S., Gon Kim, B., \& Kim, H. (2012). An integrated view of knowledge management for performance. Journal of Knowledge management, 16(2), 183-203.

Li, S., Easterby-Smith, M., Lyles, M. A., \& Clark, T. (2016), Tapping the power of local knowledge: A local-global interactive perspective. Journal of World Business, 51(4), 641-653.

Lin, C., Tsai, H. L. and Wu, J. C. (2014), Collaboration strategy decision-making using the Miles and Snow typology. Journal of Business Research, 67(9), 1979-1990.

Lukas, Bryan A. (1999), Strategic fit, market orientation, and the balance between adaptability and adaptation. Journal of Business Research, 45(2), 147-156.

Luo, Y., \& Peng, M. W. (1999), Learning to compete in a transition economy: Experience, environment, and performance. Journal of International Business Studies, 30 (2): 269-295.

Luo, Y., \& Park, S. H. (2001), Strategic alignment and performance of market-seeking MNCs in China. Strategic Management Journal, 22(2), 141-155. 
Luo, Y., Tan, J. J., \& O'connor, N. G. (2001). Strategic response to a volatile environment: The case of cross-cultural cooperative ventures. Asia Pacific Journal of Management, 18(1), 7-25.

Lyles, M. A. (1994), The impact of organizational learning on joint venture formations. International Business Review, 3(4), 459-467.

Lyles, Marjorie A. and Jane E. Salk (1996), "Knowledge Acquisition from Foreign Parents in International Joint Ventures: An Empirical Examination in the Hungarian Context," Journal of International Business Studies, 27(5), 877-903.

Manfredi Latilla, V., Frattini, F., Messeni Petruzzelli, A. and Berner, M. (2018), Knowledge management, knowledge transfer and organizational performance in the arts and crafts industry: a literature review. Journal of Knowledge Management, 22(6), 1310-1331.

March, J. G. (1991). Exploration and exploitation in organizational learning. Organization science, 2(1), 71-87.

McCann, J. E. (1991), Patterns of growth, competitive technology, and financial strategies in young ventures. Journal of Business Venturing, 6(3), 189-208.

McDaniel, S. W., \& Kolari, J. W. (1987). Marketing strategy implications of the Miles and Snow strategic typology. Journal of Marketing, 51(4), 19-30.

McEvily, S. K., and Chakravarthy, B. (2002), The persistence of knowledge-based advantage: an empirical test for product performance and technological knowledge. Strategic Management Journal, 23(4), 285-305.

McKee, D. O., Varadarajan, P. R., \& Pride, W. M. (1989). Strategic adaptability and firm performance: a market-contingent perspective. Journal of Marketing, 53(3), 21-35.

Meyer, K. E. (1998), Direct investment in economies in transition. E. Elgar, UK

Meyer, K.E. and Peng, M.W.( 2005), Probing theoretically into Central and Eastern Europe: transactions, resources, and institutions. Journal of International Business Studies 36 (6), 600-621

Meyer, K. E. and Peng, M. W. (2016), Theoretical foundations of emerging economy business research. Journal of International Business Studies, 47(1), 3-22.

Meyer, K. E. and Su, Y. S. (2015), Integration and responsiveness in subsidiaries in emerging economies. Journal of World Business, 50(1), 149-158.

Miles R.E., Snow C.C. (1978) (2003), Organisational Strategies, Structure and Process, McGraw-Hill, New York 
Miles, G., Snow, C. C., \& Sharfman, M. P. (1993). Industry variety and performance. Strategic Management Journal, 14(3), 163-177.

Miller, D., \& Friesen, P. H. (1983). Successful and unsuccessful phases of the corporate life cycle. Organization studies, 4(4), 339-356.

Mills, A. M., \& Smith, T. A. (2011). Knowledge management and organizational performance: a decomposed view. Journal of knowledge management, 15(1), 156-171.

Miner, A. S., Bassoff, P. and Moorman, C. (2001), Contours of organizational improvisation and learning. Administrative Science Quarterly, 46, 304-337.

Mintzberg, H. (1978). Patterns in strategy formation. Management science, 24(9), 934948.

Mudambi, R., Pedersen, T., and Andersson, U. (2014), How subsidiaries gain power in multinational corporations. Journal of World Business, 49(1), 101-113.

Najafi-Tavani, Z., Giroud, A. and Andersson, U. (2014), The interplay of networking activities and internal knowledge actions for subsidiary influence within MNCs. Journal of World Business, 49(1), 122-131.

Najafi-Tavani, Z., Robson, M. J., Zaefarian, G., Andersson, U., \& Yu, C. (2018). Building subsidiary local responsiveness:(When) does the directionality of intrafirm knowledge transfers matter?. Journal of World Business, 53(4), 475492.

Nonaka, Ikujiro (1994), A Dynamic Theory of Organizational Knowledge Creation, Organizational Science, 5(1), 14-37.

Nonaka, I. and Takeuchi, H. (1995). The knowledge-creating company: How Japanese companies create the dynamics of innovation. Oxford university press.

Nonaka, I. and Teece, D. (eds) (2001), Managing Industrial Knowledge: Creation, Transfer and Utilization. Thousand Oaks, CA: Sage

Ofer, G. and Polterovich, V. (2000), Modern economics education in test, Technology transfer to Russia. Comparative Economic Studies, 2(2), 5-35.

Ostry, S. and Gestrin, M. (1993), Foreign direct investment, technology transfer and the innovation- network model. Transnational Corporations, 2(3), 7-30.

Pehrsson, A. (2009). Marketing strategy antecedents of value adding by foreign subsidiaries. International Marketing Review, 26(2), 151-171. 
Peng, M. W. (2000), Business strategies in transition economies. Sage.USA

Peng, M. W. and Luo, Y. (2000), Managerial ties and firm performance in a transition economy: The nature of a micro-macro link. Academy of Management Journal, 43(3), 486-501.

Peng, M. W., Tan, J., \& Tong, T. W. (2004). Ownership types and strategic groups in an emerging economy. Journal of Management studies, 41(7), 1105-1129.

Pereira, V., Mellahi, K., Temouri, Y., Patnaik, S. and Roohanifar, M. (2018), Investigating dynamic capabilities, agility and knowledge management within EMNEs-longitudinal evidence from Europe. Journal of Knowledge Management. https://doi.org/10.1108/JKM-06-2018-0391

Peterson, M. F. (2016), A culture theory commentary on Meyer and Peng's theoretical probe into Central and Eastern Europe. Journal of International Business Studies, 47(1), 33-43.

Petrakos, G. (2013). The spatial impact of east-west integration in Europe. Integration and Transition in Europe, e book (pp. 56-86). Routledge. London https://doi.org/10.4324/9780203354469

Peltokorpi, V. and Yamao, S. (2017), Corporate language proficiency in reverse knowledge transfer: A moderated mediation model of shared vision and communication frequency. Journal of World Business, 52(3), 404-416.

Pinto, J. C. and Curto, J. D. (2007), The Organizational Configuration Concept as a Contribution to the Performance Explanation:: The Case of the Pharmaceutical Industry in Portugal. European Management Journal, 25(1), 60-78.

Porter, M. E. (1985). Technology and competitive advantage. Journal of business strategy, 5(3), 60-78.

Rajagopalan, N. (1997). Strategic orientations, incentive plan adoptions, and firm performance: Evidence from electric utility firms. Strategic Management Journal, 18(10), 761-785.

Riley, S. M., \& Hogan, E. A. (2016). Viewing the miles and snow framework through a real options lens. Academy of Strategic Management Journal, 15(2), 84-98.

Robertson, C. J., Yaghmour, M. A., \& Kawther, E. H. (2015). Perceptions of international strategic moves: Saudi Arabia versus the United States. South African Journal of Business Management, 46(2), 55-63.

Sallee, A. and Flaherty, K. (2003), Enhancing salesperson trust: an examination of managerial values, empowerment, and the moderating influence of SBU strategy Journal of Personal Selling and Sales Management 23(4): 299-310. 
Sanchez, R. and Mahoney, J.T. (1996), Modularity, flexibility and knowledge management in product and organization design. Strategic Management Journal. 17(Winter), 63-76.

Sanchez-Vidal, M. E., Sanz-Valle, R. and Barba-Aragon, M. I. (2018), Repatriates and reverse knowledge transfer in MNCs. The International Journal of Human Resource Management, 29(10), 1767-1785.

Schultz, M. and Jobe, L.A. (2001), Codification and tacitness as knowledge management strategies: An empirical exploration. Journal of High Technology Management Research, 12(1), 139-165

Segev, E. (1989). A systematic comparative analysis and synthesis of two business-level strategic typologies. Strategic Management Journal, 10(5), 487-505.

Sinkula, James M., William E. Baker and Thomas Noordewier (1997), “A Framework for Market-Based Organizational Learning: Linking Values, Knowledge, and Behavior," Journal of the Academy of Marketing Science, 25(4), 306-318.

Sheng, M. L., Hartmann, N. N., Chen, Q., \& Chen, I. (2015), The synergetic effect of multinational corporation management's social cognitive capability on tacitknowledge management: product innovation ability insights from Asia. Journal of International Marketing, 23(2), 94-110.

Slater, S. and Olson, E (2000), Strategy type and performance: the influence of sales force management Strategic Management Journal 21(8): 813-829.

Slater, S. F., Olson, E. M. and Hult, G. T. M. (2006), The moderating influence of strategic orientation on the strategy formation capability-performance relationship. Strategic Management Journal, 27(12), 1221-1231.

Slater, S. F., Olson, E. M. and Hult, G. T. M. (2010), Worried about strategy implementation? Don't overlook marketing's role. Business Horizons, 53(5), 469-479.

Smith, K. G., Guthrie, J. P., \& Chen, M. J. (1986, August). Miles and Snow's Typology of Strategy, Organizational Size and Organizational Performance. In Academy of Management proceedings (Vol. 1986, No. 1, pp. 45-49). Briarcliff Manor, NY 10510: Academy of Management.

Snow, C. C., \& Hambrick, D. C. (1980). Measuring organizational strategies: Some theoretical and methodological problems. Academy of Management Review, 5(4), $527-538$. 
Snow, C.C. and L.G. Hrebiniak (1980), "Strategy, Distinctive Competence and Organizational Performance," Administrative Science Quarterly, 259June), 317336.

Song, M., Di Benedetto, C. A. and Nason, R. W. (2007), Capabilities and financial performance: the moderating effect of strategic type. Journal of the Academy of Marketing Science, 35(1), 18-34.

Spender, J. C. (1996), Making knowledge the basis of a dynamic theory of the firm. StrategicManagement Journal, 17(S2), 45-62.

Sperber, A. D., Devellis, R. F. and Boehlecke, B. (1994), Cross-cultural translation: methodology and validation. Journal of cross-cultural psychology, 25(4), 501524.

Stojcic, N., Hashi, I., \& Telhaj, S. (2011). Innovation activities and competitiveness: Empirical evidence on the behaviour of firms in the new EU member states and candidate countries. CASE Network Studies and Analyses, (424).

Stor, M., Poór, J., Szabo, K., Slavić, A., Zaharie, M. and Machova, R. (2016), The Emerging Outline of Selected HRM Business Practices In MNC In Central Europe-The Empirical Research Findings. Journal of Intercultural Management, 8(3), 105-137.

Stuart, T. E. and Podolny, J. M. (1996), Local search and the evolution of technological capabilities. Strategic Management Journal, 17(S1), 21-38.

Teece, D. J. (1998), Capturing value from knowledge assets: The new economy, markets for know-how, and intangible assets. California management review, 40(3), 5579.

Teece, D. J. (2000), Strategies for managing knowledge assets: the role of firm structure and industrial context. Long range planning, 33(1), 35-54.

Tenhiälä, A., \& Laamanen, T. (2018). Right on the money? The contingent effects of strategic orientation and pay system design on firm performance. Strategic Management Journal, 39(13), 3408-3433.

Thomas, J. C., Kellogg, W. A. and Erickson, T. (2001), The knowledge management puzzle: Human and social factors in knowledge management. IBM systems journal, 40(4), 863-884.

Tihanyi, L. and Roath, A. S. (2002), Technology transfer and institutional development in Central and Eastern Europe. Journal of World Business, 37(3), 188-198. 
Uhlenbruck, K and De Castro, J. (2000), Foreign acquisitions in Central and Eastern Europe, Outcomes of privatization in transitional economies. Academy of Management Journal, 43, 381-402.

Venaik, Sunil, and David F. Midgley. "Archetypes of marketing mix standardizationadaptation in MNC subsidiaries: Fit and equifinality as complementary explanations of performance." European Journal of Marketing 53, no. 2 (2019): 366-399.

Vlajčić, D., Caputo, A., Marzi, G. and Dabić, M. (2019), Expatriates managers' cultural intelligence as promoter of knowledge transfer in multinational companies. Journal of Business Research, 94, 367-377.

Wadhwa, P., McCormick, M., \& Musteen, M. (2017). Technological innovation among internationality active SMEs in the Czech economy: Role of human and social capital of CEO. European Business Review, 29(2), 164-180.

Wei, Z., \& Nguyen, Q. T. (2017), Subsidiary strategy of emerging market multinationals: A home country institutional perspective. International Business Review, 26(5), 1009-1021.

Wilden, R., Gudergan, S. and Lings, I. (2018), The interplay and growth implications of dynamic capabilities and market orientation. Industrial Marketing Management. On line first https://doi.org/10.1016/j.indmarman.2018.11.001

Youssef, M., Haak-Saheem, W., \& Youssef, E. M. (2017). A structural equation model for knowledge sharing behavior in an emerging economy. Journal of Knowledge Management, 21(4), 925-945.

Zahra, S. A., Ireland, R. D., \& Hitt, M. A. (2000), International expansion by new venture firms: International diversity, mode of market entry, technological learning, and performance. Academy of Management Journal, 43(5), 925-950.

Zeng, R., Grøgaard, B.and Steel, P. (2018), Complements or substitutes? A metaanalysis of the role of integration mechanisms for knowledge transfer in the MNE network. Journal of World Business, 53(4), 415-432. 


\section{TABLE 1}

Knowledge Management Second-Order Factor Structure

\begin{tabular}{|c|c|c|c|}
\hline First-Order Factor & Knowledge & Knowledge & Knowledge \\
\hline Loadings & & & \\
\hline & Acquisition & Conversion & Application \\
\hline KAC1 & $.699^{\mathrm{a}}$ & & \\
\hline $\mathrm{KAC} 2$ & $.792(8.200)$ & & \\
\hline KAC3 & $.838(7.373)$ & & \\
\hline KAC4 & $.666(10.170)$ & & \\
\hline $\mathrm{KC} 1$ & & $.760^{\mathrm{a}}$ & \\
\hline $\mathrm{KC} 2$ & & $.850(10.103)$ & \\
\hline $\mathrm{KC} 3$ & & $.855(10.170)$ & \\
\hline KAP1 & & & $.652(8.667)$ \\
\hline KAP2 & & & .900 \\
\hline & & & (10.258) \\
\hline KAP3 & & & $.729^{\mathrm{a}}$ \\
\hline KAP4 & & & $.856(9.755)$ \\
\hline Second-Order Factor & Knowledge & & \\
\hline
\end{tabular}




\begin{tabular}{|l|r|r|r|r|}
\hline Descriptive & Statistics & & & \\
\hline KA TOT & Minimum & Maximum & Mean & Std. Deviation \\
\hline KC TOT & 1.6 & 7 & 4.319 & 1.3955 \\
\hline AP TOT & 1 & 7 & 4.1 & 1.478 \\
\hline LY Perf & 2 & 7 & 4.44 & 1.244 \\
\hline
\end{tabular}


TABLE 2

Means, Standard Deviations and Correlations

\begin{tabular}{|c|c|c|c|c|c|c|c|c|c|c|c|c|}
\hline & Mean & S.D. & 1 & 2 & 3 & 4 & 5 & 6 & 7 & 8 & 9 & 10 \\
\hline 1. Prospector & .37 & .48 & & & & & & & & & & \\
\hline 2. Analyzer & .31 & .47 & $-.513 * *$ & & & & & & & & & \\
\hline 3. Defender & .11 & .31 & $-.263 * *$ & $-.233 * *$ & & & & & & & & \\
\hline 4. Reactor & .21 & .51 & $-.310 * *$ & $-.275^{* *}$ & -.141 & & & & & & & \\
\hline 5. Market Dynamism & 4.60 & 1.54 & $.437 * *$ & -.135 & $-.233 * *$ & $-.269 * *$ & & & & & & \\
\hline 6. Competitive Intensity & 5.04 & 1.70 & $.369 * *$ & -.037 & $-.196 * *$ & $-.356 * *$ & $.511 * *$ & & & & & \\
\hline 7. Knowledge Management & 4.31 & 1.32 & $.449 * *$ & -.088 & $-.293 * *$ & $-.279 * *$ & $.490 * *$ & $.301 * *$ & & & & \\
\hline 8. Performance & 3.78 & 1.71 & $.240 * *$ & -.010 & $-.212 *$ & -.098 & $.428 * *$ & $.357 * *$ & $.551 * *$ & & & \\
\hline 9. Number of Employees & 1075 & 5974 & -.08 & .128 & -.047 & -.008 & $-.189 *$ & .042 & .098 & -.112 & & \\
\hline 10. Experience & 14.41 & 9.10 & .167 & -.089 & $-.218 *$ & .145 & .117 & $.262 *$ & .139 & -.010 & .121 & \\
\hline 11. International Experience & 20.00 & 20.31 & -.121 & .003 & .097 & .018 & -.1448 & -.176 & -.075 & -.056 & -.004 & .048 \\
\hline
\end{tabular}

** Correlation is significant at the .01 level

* Correlation is significant at the .05 level 
TABLE 3

Discriminant Analysis of the Environment-strategy Alignment

\begin{tabular}{lll}
\hline Variables & Correlation & Standardized \\
& Coefficients & Coefficients \\
\hline Dependent & & \\
Strategy & & \\
Independent & .647 & .859 \\
Competitive Intensity & .554 & .801 \\
Market Dynamism & & \\
Eigenvalue & .366 & \\
Canonical Correlation & .518 & \\
Eta-square & .268 & \\
\hline
\end{tabular}

TABLE 4

Analysis of Variance Results of Strategy-knowledge Management Capabilities Linkage

\begin{tabular}{llllll}
\hline & Sum of & & Mean & & \\
& Squares & df & Square & F & Sig. \\
\hline Strategy & 23.676 & 3 & 7.892 & 6.001 & .001 \\
Firm Size & .519 & 1 & .519 & .395 & .532 \\
Years of International Experience & 1.986 & 1 & 1.986 & 1.510 & .223 \\
Industry & .861 & 1 & .861 & .655 & .421 \\
Error & 88.108 & 67 & 1.315 & & \\
Total & 1575.575 & 74 & & & \\
\hline
\end{tabular}




\section{TABLE 5}

\section{Multiple Regression Results Knowledge Management Capabilities to Performance Linkage}

Dependent Variable: Subsidiary Performance

\begin{tabular}{llcc} 
& Standardized & & \\
Independent Variable & Coefficients & t-value & p-value \\
\hline Knowledge Management & .551 & 5.037 & .000 \\
Firm Size & .008 & .076 & .940 \\
Years of International Experience & .003 & .031 & .975 \\
Industry & .036 & .357 & .722 \\
\hline
\end{tabular}

$\mathrm{F}(4,71)=6.567, \mathrm{p}<.000, \mathrm{R}^{2}=.270$, Adjusted $\mathrm{R}^{2}=.229$ 
Table 6: Performance to Strategic Orientation:

Legend: 1-Prospector 2- Analyzer 3- Defender 4 - Reactor

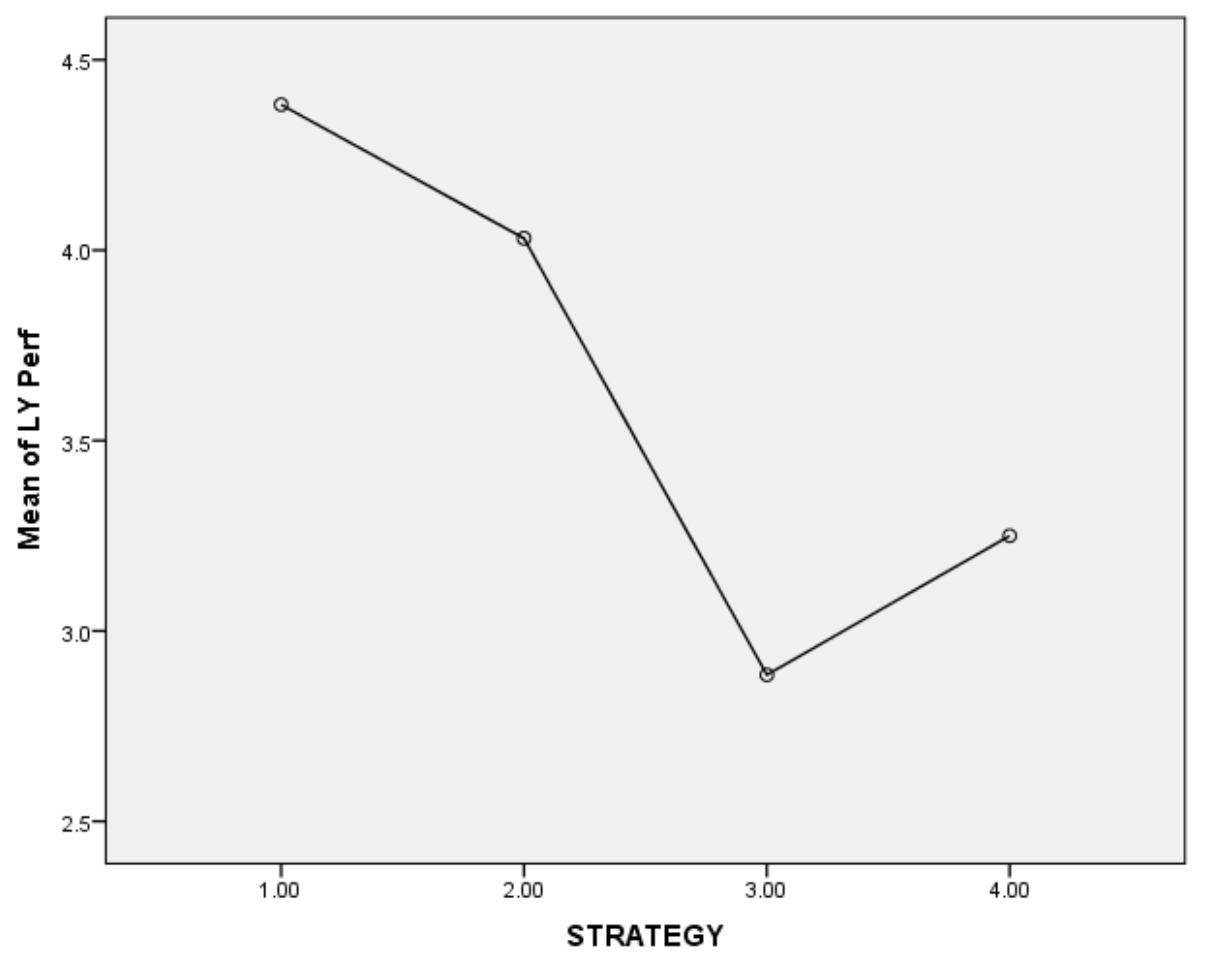


Table 7: Significance of Differences in Strategic Orientation

Multiple Comparisons

Dependent VLYPerf

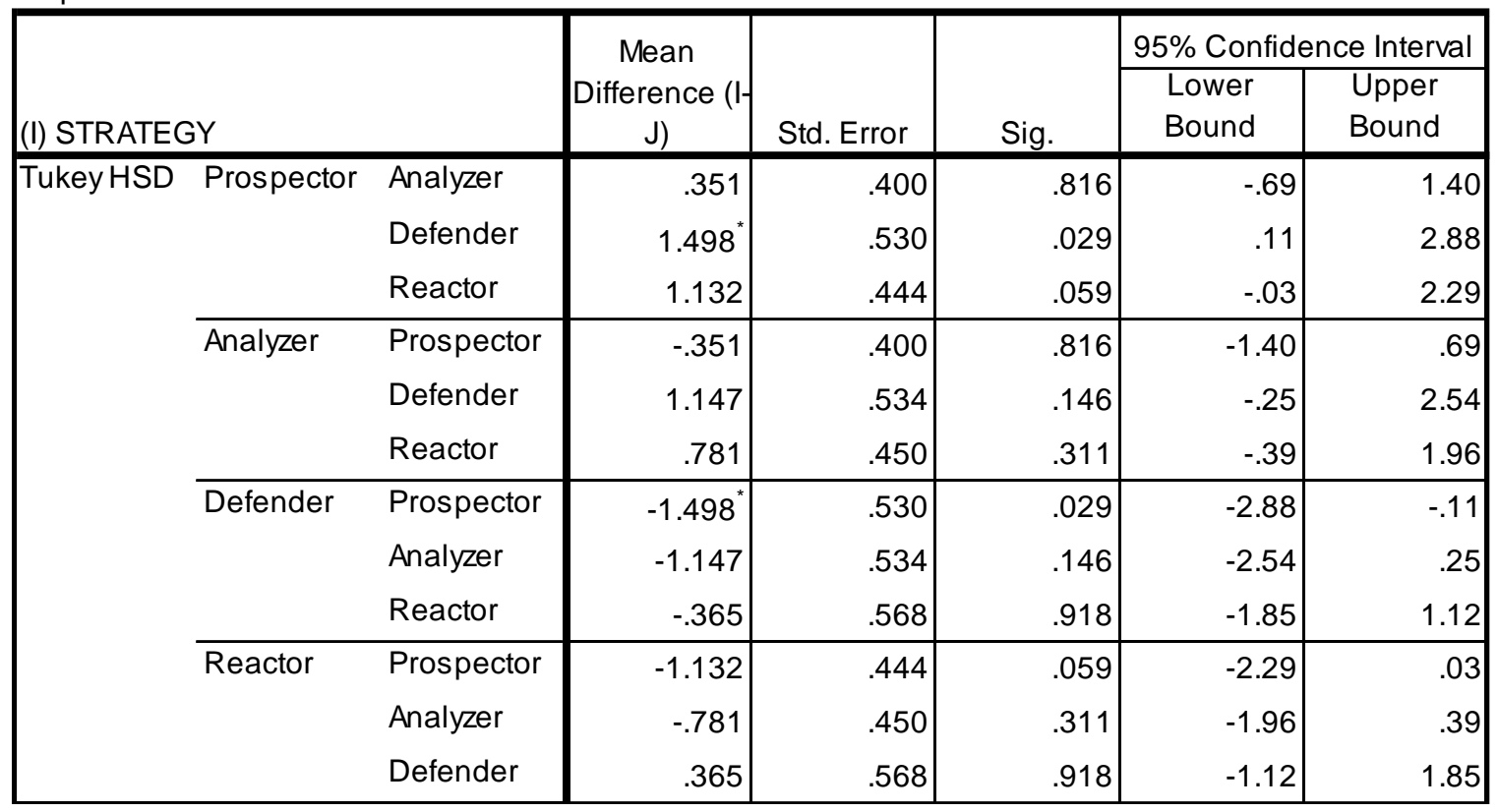

*. The mean difference is significant at the 0.05 level. 
Exhibit 1: Knowledge Management Measures

Knowledge Management

Measures (All derived from Gold et al., 2001)

Acquisition-oriented

Your Firm: (7-point likert scale)

(1) has processes for generating new knowledge from existing knowledge

(2) uses feedback from customers and business partners to improve subsequent products and services

(3) has processes for integrating different sources and types of knowledge,

(4) has processes for acquiring knowledge about its business partners

(5) has processes for exchanging knowledge with its business partners

Conversion-oriented

Your Firm: (7-point likert scale)

(1) has ways of converting knowledge into the design of new products or services

(2) has processes for integrating different sources and types of knowledge

(3) has processes for organizing knowledge

(4) has processes for converting competitive intelligence into plans of action

Application-oriented Your Firm: (7-point likert scale)

(1) applies knowledge learned from mistakes

(2) takes advantage of new knowledge

(3) applies knowledge learned from experiences

(4) uses knowledge to solve new problems

Market Dynamism $\quad$ Measures (Derived from Jap, 1999)

(1) the environment demands on our firm are constantly changing

(2) the business practices in our industry are constantly changing. 